\title{
Tracking Tumours into Number Community? - Yes, How and Why
}

\author{
W B Bozegha* \\ Numeration Science Literature, Development Research project, Department of Combinatorial Computation, Nigeria
}

Submission: March 12, 2019; Published: August 12, 2019

"Correspondence Author: W B Bozegha, Numeration Science Literature, Development Research project, Department of Combinatorial Computation, Nigeria

\begin{abstract}
Statement of the Problem: Tumours are growths (of quantity) in humans with medical science literature. Isodigitals produced by preemptive multiplication are also growths (of quantity) in numbers with slight numeration science literature for now. The developer of inchoate numeration science literature somehow acquainted with the literature of tumours, upon encountering isodigitals would be prompted to surmise isodigitals as phenotypes (lookalikes) of tumours and be urged to explore their literatures for prospects of relationship between the two.

Methodology and theoretical Orientation: Tumours and isodigitals are subjected to pentadic characterization with the five parameters of identity, structure, function, operation and application for methodology. The theoretical orientation of the method is that tumours and isodigitals as growths of quantity are classic examples of quantity which is defined as the phenomenal medium of manifestation of all things, whether material or non-material. So, the two can be compared and contrasted at will in the interest of science.
\end{abstract}

Findings: Numeration science literature on isodigitals can borrow mode of classification of tumours from medical science literature on tumours, while medical science literature on tumours can borrow verbal formulary for the description of pattern of growth of tumours from numeration science literature on isodigitals.

Conclusion and Significance: Tumours in humans and isodigitals in numbers are seen as phenotypes subsisting on manifestation of quantity. The peculiarities of one can serve as clues to the probing of the other for more light.

Recommendations: The ideal of insight on quantity should be brought to bear on scientific engagements.

Keywords: Tumours; Isodigitals; Borrowing; Classification; Literature

\section{Introduction}

Pre-emptive Multiplication in Numeration Science Literature produces isodigitals (numbers with repeated digits at one or more sites in individual numbers) rather selectively from sudit family lineages in some spectacular architectural design as shown in Charts $1 \& 2$ that is easily described. The isodigital sites of such numbers look swollen and resemble swollen tissues in humans, which are called tumours in medical science. So the look-alikes (phenotypes) of tumours identified as isodigitals are encountered in some number communities. These isodigitals and tumours are subjected to comparison on this occasion on the ground that both are examples of QUANTITY which is defined in Numeration Science as phenomenal medium of manifestation of all things, whether material or non-material. The comparison includes pentadic characterization with as many as five parameters viz identity, structure, function, operation and application as rungs for exploring the ladder of similarity between the two as shown in Table 1.

\section{Materials and Methods}

\section{Materials}

The materials are digital and consist of the nine counting digits 1,2,3,4,5,6,7,8,9 distributed in the three Sudit Family Lineages of 1, 4, 7 in Family 1, 2, 5, 8 in Family 2; and 3,6,9 in Family 3 as shown in Chart 1 and the numeral 11 in Chart 2 .

\section{Methods}

The methods are three: first Isodigital Square Multiplication (ISM). In Sudit family lineages under progressively increasing Digitality Level Arrangement (DLA) levels Chart 1 and the second of Base 11 Potentiation Multiplication under progressively increasing power (n) Chart 2, and the third of Base 10 digibreed construction involving Successive Collateral Posting (SCP), ref. Chart 3 are done as shown in Charts 1 and 2 respectively. The contents of the two charts are studied and regularities in the results of ISM of Family 3 in Chart 1 and that of potentiation 


\section{Cancer Therapy \& Oncology International Journal}

multiplication of isodigital base 11 Chart 2 are discovered and is a newly invented brand of multiplication in inchoate micro-

identified as examples of pre-emptive multiplication, which mathematics being developed by this author.

Chart 1: Isodigital Square Multiplication in Sudit Family Lineages, 1-9

\begin{tabular}{|c|c|c|c|c|c|c|c|c|c|c|c|}
\hline \multirow{2}{*}{$\begin{array}{l}\text { Sudit } \\
\text { Fami- } \\
\text { ly No. }\end{array}$} & \multirow{2}{*}{$\begin{array}{l}\text { Sudit } \\
\text { Family } \\
\text { Index }\end{array}$} & \multirow{2}{*}{$\begin{array}{l}\text { Sudit } \\
\text { Family } \\
\text { Lin- } \\
\text { eage }\end{array}$} & \multicolumn{8}{|c|}{ Isodigital Square Multiplicaiton (ISM) in Digitality Level Arrangements (DLA's) } & \multirow[b]{2}{*}{ Remarks } \\
\hline & & & OP & DLA 1 & DLA 2 & $\begin{array}{c}\text { DLA } \\
3\end{array}$ & $\begin{array}{c}\text { DLA } \\
4\end{array}$ & $\begin{array}{c}\text { DLA } \\
5\end{array}$ & $\begin{array}{l}\text { DLA } \\
6\end{array}$ & $\begin{array}{c}\text { DLA } \\
7\end{array}$ & \\
\hline \multirow{8}{*}{1} & \multirow{8}{*}{$.3333 \ldots$} & & ISM & $1 \times 1$ & $11 \times 11$ & $111 \times 111$ & $1111 \times 1111$ & $11111 \times 11111$ & $111111 \times 111111$ & $1111111 x 1111111$ & \\
\hline & & & $\mathrm{P}$ & 1 & 121 & 12321 & 1234321 & 123454321 & 12345654321 & 1234567654321 & CSF \\
\hline & & 1 & CAT & \multicolumn{7}{|c|}{$\begin{array}{l}\text { Common growth pattern (CGP) } \\
\text { Ascend serially from } 1 \text { to DLA index and descend serially back to } 1\end{array}$} & $\begin{array}{l}\text { V.F. Featuring } \\
\text { Kenization } \\
\text { Dekenization }\end{array}$ \\
\hline & & \multirow{3}{*}{4} & ISM & $4 \times 4$ & $44 \times 44$ & $444 \times 444$ & $4444 \times 4444$ & $44444 \times 44444$ & $444444 \times 444444$ & $4444444 \times 4444444$ & \\
\hline & & & $\mathrm{P}$ & 16 & 1936 & 197136 & 19749136 & 1975269136 & 197530469136 & 19753082469136 & $\begin{array}{l}\text { Common } \\
\text { RODI only }\end{array}$ \\
\hline & & & CAT & \multicolumn{7}{|c|}{ NCGP } & NVF \\
\hline & & \multirow[b]{2}{*}{7} & ISM & $7 \times 7$ & $77 \times 77$ & $777 \times 777$ & $7777 \times 7777$ & $77777 \times 77777$ & $777777 \times 777777$ & 7777777x7777777 & \\
\hline & & & $\mathrm{P}$ & 49 & 5929 & 603729 & 60481729 & 6049261729 & 604937061729 & 60493815061729 & $\begin{array}{l}\text { Common } \\
\text { RODI only }\end{array}$ \\
\hline \multirow{10}{*}{2} & \multirow{10}{*}{$.6666 \ldots$} & \multirow{4}{*}{2} & CAT & \multicolumn{7}{|c|}{ NCGP } & \multirow[t]{2}{*}{ NVF } \\
\hline & & & ISM & $2 \times 2$ & $22 \times 22$ & $222 \times 222$ & $2222 \times 2222$ & $22222 \times 22222$ & $222222 \times 222222$ & $2222222 \times 2222222$ & \\
\hline & & & $\mathrm{P}$ & 4 & 484 & 49284 & 4937284 & 493817284 & 49382617284 & 4938270617284 & $\begin{array}{l}\text { Common } \\
\text { RODI only }\end{array}$ \\
\hline & & & CAT & \multicolumn{7}{|c|}{ NCGP } & NVF \\
\hline & & \multirow{3}{*}{5} & ISM & $5 \times 5$ & $55 \times 55$ & $555 \times 555$ & $5555 \times 5555$ & $55555 \times 55555$ & $555555 \times 555555$ & $5555555 \times 5555555$ & \\
\hline & & & $\mathrm{P}$ & 25 & 3025 & 308025 & 30858025 & 3086358025 & 308641358025 & 30864191358025 & $\begin{array}{c}\text { Common } \\
\text { ultimate \& } \\
\text { penultimate }\end{array}$ \\
\hline & & & CAT & \multicolumn{7}{|c|}{ NCGP } & NVF \\
\hline & & \multirow{3}{*}{8} & ISM & $8 \times 8$ & $88 x 88$ & 888x888 & 8888x8888 & 88888x88888 & 888888x888888 & 8888888x8888888 & \\
\hline & & & $\mathrm{P}$ & 64 & 7744 & 788544 & 78996544 & 7901076544 & 790121876544 & 7901239876544 & $\begin{array}{l}\text { Common } \\
\text { RODI only }\end{array}$ \\
\hline & & & CAT & \multicolumn{7}{|c|}{ NCGP } & NVF \\
\hline
\end{tabular}

KEY

CSF: Common Structural Frame; ISM: Isodigital Square Multiplication; OP: Multiplication Operation under increasing DLA levels; P: Product; CAT: Category (of product) in terms of uniform structure amenable to verbal formula (VF) or else not amenable to verbal formula (NVF). CGP: Common Growth Pattern, NCGP = No Common Growth Pattern; L: Leading Digit in DLA 1 Product LT (Gamete); T: Trailing Digit in DLA 1 Product LT (Gamete); VFFKD : Verbal Formula Featuring Kenization and Dekenization

Note: With verbal formula, products of DLA 8, 9,10 etc can be obtained without calculation exercise in ISM, thus giving rise to systematization in Pre-emptive Multiplication.

Chart 2: Isodigital base 11 potentiation multiplication.

\begin{tabular}{|c|c|c|c|c|c|c|c|c|c|c|}
\hline \multirow[t]{2}{*}{$\begin{array}{l}\text { Isodigital } 11 \text { potentiation } \\
\text { multiplication }\left(11^{\text {n }}\right)\end{array}$} & & \multicolumn{9}{|c|}{$11^{\mathrm{n}}$ or $(11$ to power $(\mathrm{n})$} \\
\hline & 11 & $11^{1}$ & $11^{2}$ & $11^{3}$ & $11^{4}$ & $11^{5}$ & $11^{6}$ & $11^{7}$ & $11^{8}$ & $11^{9}$ \\
\hline Product & 1 & 11 & 121 & 1331 & 14441 & 15551 & 1666661 & 17777771 & 188888881 & 1999999991 \\
\hline Verbal formula & \multicolumn{10}{|c|}{ The power index (n) replicated (n-1) times and sandwiched in 11, (so that the product has 1 in front and 1 behind). } \\
\hline
\end{tabular}

Chart 3: Base -10 Digibreed Construction by Successive Collateral Posting Method.

\begin{tabular}{|l|l|l|l|l|l|l|l|l|l|l|l|}
\hline Corridor & 0 & 1 & 2 & 3 & 4 & 5 & 6 & 7 & 8 & 9 \\
strength \\
in panel
\end{tabular}




\section{Cancer Therapy \& Oncology International Journal}

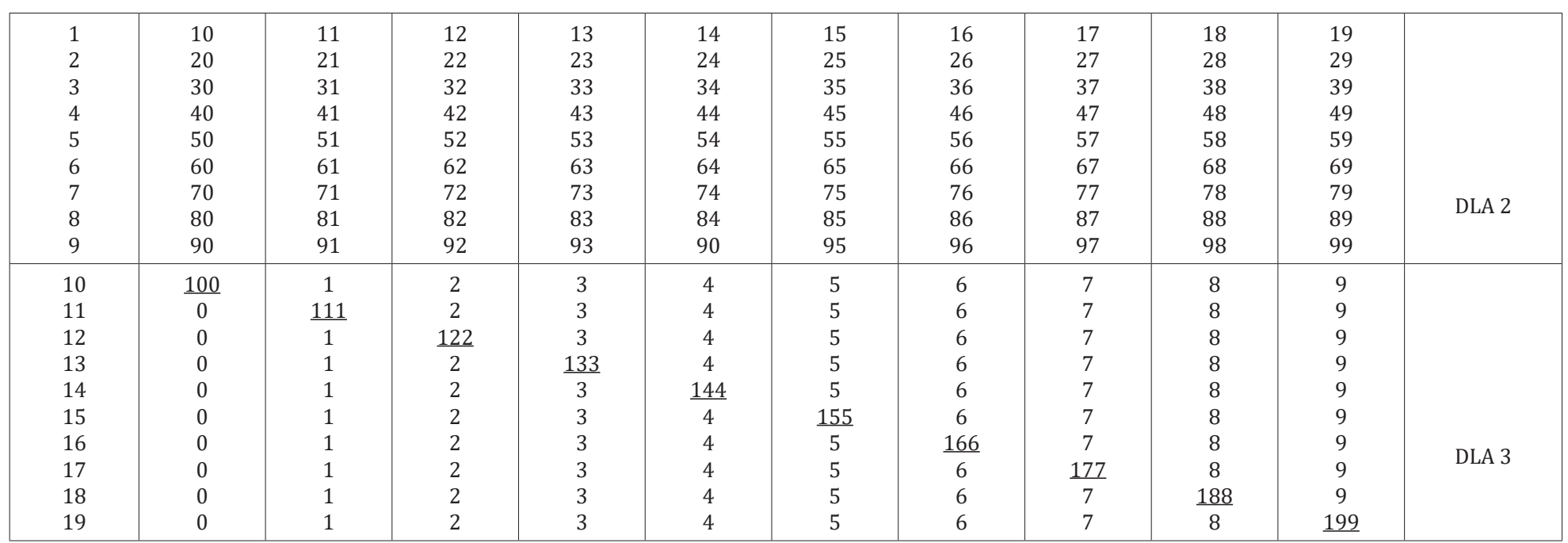

Table 1: Pentadic Characterization of Isodigitals and Tumours.

\begin{tabular}{|c|c|c|c|}
\hline \multicolumn{2}{|c|}{ Pentadic Characterization parameters } & \multicolumn{2}{|c|}{ Duo } \\
\cline { 2 - 4 } S/No 1 & Identity (what is it by name or class) & $\begin{array}{c}\text { Growth manifested in a location involving } \\
\text { isodigits in numbers }\end{array}$ & $\begin{array}{c}\text { Growth manifested in a location involving } \\
\text { cells in human tissue }\end{array}$ \\
\hline 2 & $\begin{array}{c}\text { Structure (shape, size, content, systemic, } \\
\text { configuration etc) }\end{array}$ & Entity well defined in outline & Entity well defined in outline \\
\hline 3 & Function & Attention calling, Spectacular & Attention calling, Spectacular \\
\hline 4 & Operation & $\begin{array}{c}\text { Growing upon due excitement, exhibiting } \\
\text { intrinsic properties }\end{array}$ & $\begin{array}{c}\text { Growing upon due excitement, exhibiting } \\
\text { intrinsic properties }\end{array}$ \\
\hline 5 & Application & $\begin{array}{c}\text { Significance or peculiarities as reference } \\
\text { point for further probing or research effort }\end{array}$ & $\begin{array}{c}\text { Significance or peculiarities as reference } \\
\text { point for further probing or research } \\
\text { effort. }\end{array}$ \\
\hline
\end{tabular}

The construction is continued by transferring $10-19$ in row 2 to the second segment of the corridor as shown in Chart 3. The nine rows thus filled carry the digibreed to 99 preceded by $0-9$ in the panel. Counting, however, starts at 1 and not 0 as 0 is not a counting digit. Step 1 requires the placement of the base strength of base 10 i.e. the ten digits 0-9 from left to right in the panel as shown in Charts 3. Step 2 transfers the counting digits 1-9 only into the corridor, descending serially from 1 to 9 . Step
3 requires the membership of the base strength in the panel to descend nine places in their respective columns according to the membership in the topmost segment of the corridor. Step 4 requires each digit in the corridor to move to the left side of each digit in the row under the panel (Table 1).

\section{Results}

(Tables $2 \& 3$ ).

Table 2: Table of Isodigitals, the Phenotypes of Tumors.

\begin{tabular}{|c|c|c|c|c|c|c|c|}
\hline S/No & \multicolumn{5}{|c|}{ Isodigitals } & Source & Remarks \\
\hline \multirow{3}{*}{1} & 110889 & 11108889 & 1111088889 & 111110888889 & 11111108888889 & \multirow{3}{*}{$\begin{array}{l}\text { Chart } 1 \text { Sudit Family } \\
\text { No. } 3 \text { lineages 3,6, } 9 \\
\text { in DLA 3-DLA } 7\end{array}$} & \multirow{3}{*}{$\begin{array}{l}\text { Common configuration } \\
\text { amenable to description by } \\
\text { verbal formula for pattern }\end{array}$} \\
\hline & 443556 & 44435556 & 4444355556 & 444443555556 & 44444435555556 & & \\
\hline & 998001 & 99980001 & 9999800001 & 999998000001 & 99999980000001 & & \\
\hline 2 & 1331 & 14441 & 155551 & 1666661 & 17777771 & $\begin{array}{l}\text { Chart } 2 \text { from } 11^{3} \\
\text { to } 11^{7}\end{array}$ & $\begin{array}{l}\text { Common configuration } \\
\text { amendable to description by } \\
\text { verbal formula for pattern }\end{array}$ \\
\hline 3 & 121 & 12321 & 1234321 & 123454321 & 12345654321 & $\begin{array}{c}\text { Chart } 1 \text { Sudit Family } \\
1 \text { lineage } 1\end{array}$ & $\begin{array}{l}\text { Common configuration } \\
\text { amenable to description by } \\
\text { verbal formula for pattern }\end{array}$ \\
\hline \multirow{2}{*}{4} & 11 & 111 & 1111 & 11111 & 111111 & \multirow{2}{*}{$\begin{array}{l}\text { Chart } 3 \text { Base } 10 \\
\text { DIgibreed }\end{array}$} & \multirow{2}{*}{ Ditto } \\
\hline & 22 & 222 & 2222 & 22222 & 222222 & & \\
\hline
\end{tabular}




\section{Cancer Therapy \& Oncology International Journal}

\section{Discussion}

The scope of the discussion is determined by the extent of the hesitancy of the tracking venture as portrayed in the question opening the title, to wit: Tracking Tumours into Number Community? And the retort of assurance conveyed by Yes, How and Why concluding the title. The idea of tracking tumours into number community itself might have been extemporaneous upon seeing both tumours and isodigitals as manifestations of quantity in form of swellings. Hesitancy portrayed in the topic might have crept in upon some reflection on the classification of tumours and diagnosis of certain categories of them that are familiar lethal diseases. In effect the hesitancy is about whether the flight of the venture of tracking tumours into number community could have a soft landing on the runway littered with issues of classification, diagnosis, exploits and impact of tumours as outlined in Table 3. Fortunately, the topic starting with hesitancy ends with a retort of assurance in the three words thus: Yes, How and Why.

Table 3: Tumours vis a vis Isodigitals.

\begin{tabular}{|c|c|c|c|c|}
\hline \multirow{2}{*}{ S/No } & \multirow{2}{*}{ Particulars } & \multicolumn{2}{|r|}{ Duo } & \multirow[t]{2}{*}{ Remarks } \\
\hline & & Tumours in Medical Science & Isodigitals in Numeration Science & \\
\hline \multirow[b]{2}{*}{1} & & $\begin{array}{l}\text { (i) Into } 2 \text { categories } \\
\text { (a) Benign } \\
\text { (b) Malignant }\end{array}$ & $\begin{array}{l}\text { (1) Into } 2 \text { categories } \\
\text { (a) Pre-emptives } \\
\text { (b) Non-pre-emptives }\end{array}$ & \multirow{6}{*}{$\begin{array}{l}\text { There is remarkable } \\
\text { resemblance between } \\
\text { the two in support of } \\
\text { the analogy between } \\
\text { them and the tracking } \\
\text { of tumours in number } \\
\text { community. }\end{array}$} \\
\hline & Classification & $\begin{array}{c}\text { (ii) Subdivisions under: } \\
\text { (a) Benign } \\
\text { - The fibrous tumour (fibroma) } \\
\text { - The fatty tumour (lipoma) } \\
\text { - The nerve tumour (neuroma) } \\
\text { - The gland tumour (adenoma) } \\
\text { - The blood vessel tumor (angioma) } \\
\text { - The bony tumour (osteoma) } \\
\text { The wart (papilloma) } \\
\text { (b) Malignant (cancer) } \\
\text { - Carcinoma } \\
\text { - Sarcoma }\end{array}$ & $\begin{array}{l}\text { (ii) Subdivision also exist } \\
\text { (a) Under: Non-pre-emptives } \\
\text { - Three subdivisions (Table 2) } \\
\text { • Total } \\
\text { • Partial } \\
\text { • Twin } \\
\text { (b) Under Pre-emptives, Table } 2 \\
\text { Palindromic } \\
\text {-Peaked } \\
\text {-Plateaued } \\
\text { - Non-palindromic bifocal }\end{array}$ & \\
\hline \multirow[t]{2}{*}{2} & $\begin{array}{l}\text { Diagnosis meaning identifica- } \\
\text { tion of disease by investiga- } \\
\text { tion of symptoms and history }\end{array}$ & $\begin{array}{c}\text { Tumours characterized by intriguing } \\
\text { latencies demanding diagnosis by } \\
\text { medical professionals }\end{array}$ & $\begin{array}{c}\text { Isodigials characterized by intriguing laten- } \\
\text { cies demanding 'diagnosis' by numeration } \\
\text { experts }\end{array}$ & \\
\hline & & $\begin{array}{l}\text { Details of procedures in diagnosis are } \\
\text { better left to the medical experts in } \\
\text { specialized areas for obvious reasons }\end{array}$ & $\begin{array}{l}\text { Isodigital diagnosis here entails identifying } \\
\qquad \text { The class } \\
\text { • Other details of formation including } \\
\text { operatives and processes and formulary, as } \\
\text { presented in the text }\end{array}$ & \\
\hline 3 & Exploits & $\begin{array}{l}\text { The exploits of Tumours especially } \\
\text { the malignant brands are pathogenic } \\
\text { amongst humans and negative and } \\
\text { well known for hurting, wasting and } \\
\text { killing of victims }\end{array}$ & $\begin{array}{l}\text { The exploits for isodigitals include selectivity } \\
\text { of certain digits in the pre-emptive brands } \\
\text { initiation of kenization and dekenization } \\
\text { operations presented in the text }\end{array}$ & \\
\hline 4 & Impact & $\begin{array}{c}\text { Tumours in all ramifications are fully } \\
\text { impactful to humanity. A great concern } \\
\text { in wellbeing of man in terms of health } \\
\text { and propelling research for combating } \\
\text { them. }\end{array}$ & $\begin{array}{l}\text { Isodigitals in all ramifications are impactful } \\
\text { academically to humanity rather selectively, } \\
\text { capable of exciting academic exploration for } \\
\text { extending the frontiers of Numeration. }\end{array}$ & \\
\hline
\end{tabular}

In classification, Tumours divide into two categories namely Benign and Malignant, so do Isodigitals divide into two, namely Pre-emptives and Non-pre-emptives as shown in subdivisions of classification in Table 4. Subdivisions of classification abound in both Tumours and Isodigitals as per Table 4, where according to Medicine for Nurses, 12th Edn (1975) R26 by W. Gordon Sears and R.S. Winwood there are as many as seven subdivisions of Benign Tumours (Table 4).

\section{Isodigitation varieties and growth patterns with facilitators}

a. Peaked palindromic pre-emptive isodigitals, ref. Chart 1 and Table 3. They are products of Isodigital Square Multiplication (ISM) of digit 1 in increasing DLA indexes evident from DLA 2. The incumbent DLA index (4) of the ISM is the peak(n). The upward slope is worked in serial steps from 1 at the base to 


\section{Cancer Therapy \& Oncology International Journal}

peak (n) ie 4 by kenization process of adding 1 successively while the downward slope from peak(n) dekenization process of subtracting 1 successively to 1 at the base again as shown in Figure 1. The serial products of kenization are christened kenites, while those of dekenization are dekenites, as depicted in Figure 1. Kenization (adding 1) and dekenization (subtracting 1) working in concert produce duplicate serial isodigitation in ISM of digit 1 rather ironically in view of their opposing drives (Figure 1).

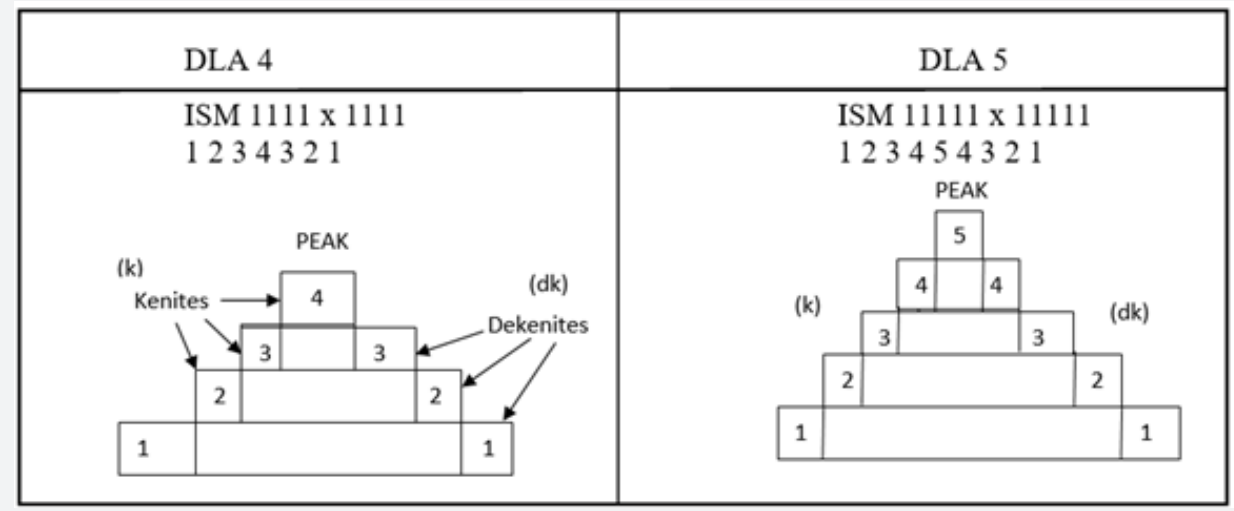

K: Kenites produced by Kenization process during ISM of 1 in increasing DLA's

Dk: Dekenites produced by Dekenization process during ISM of 1 in increasing DLA's

Figure 1: Structure and growth pattern of peaked isodigital of ISM 1.

b. Non-palindromic bifocal pre-emptive isodigitals ref. Chart 1 and Table 3. They are products of Isodigital Square Multiplication (ISM) of digits 3,6,9 all in Sudit Family 3 in increasing DLA indexes and the isodigitation appears first in DLA 3 in each case. The digital engagements in the bifocal isodigitation are phenomenal and fall into generations of development, to wit: first generation, second generation, third etc in terms of DLA index progression as depicted in Figure 2 (Tables 5 \& 6).

Table 5: Kenizites and Dekenizites ref. Figure 2.

\begin{tabular}{|c|c|c|}
\hline Part A & Kenizite for 0 of $09=1$, & Dekenizite for 9 of $09=8$ \\
\hline Part B & " " 3 of $36=4$, & " " 6 of $36=5$ \\
\hline Part C & 8 of $81=9$ & 1 of $81=0$ \\
\hline
\end{tabular}

\begin{tabular}{|llll|}
\hline ISM first digit & 3 & 6 & 9 \\
ISM DLA 1 first generation & $3 \times 3$ & $6 \times 6$ & $9 \times 9$ \\
DLA 1 Product generated & 09 & 36 & 81 \\
Leading digit/trailing digit & $\mathrm{LT}$ & $\mathrm{L}_{1} \mathrm{~T}_{1}$ & $\mathrm{~L}_{2} \mathrm{~T}_{2}$ \\
ISM DLA 2 & $33 \times 33$ & $66 \times 66$ & $99 \times 99$ \\
DLA 2 Product 2nd Generation & 1089 & 4356 & 9801 \\
ISM DLA 3 & $333 \times 333$ & $666 \times 666$ & $999 \times 999$ \\
DLA 3 Product 3rd Generation & 110889 & 443556 & 998001 \\
ISM DLA 4 & $3333 \times 3333$ & $6666 \times 6666$ & $9999 \times 9999$ \\
DLA 4 Product 4th Generation & 11108889 & 44435556 & 99980001 \\
ISM DLA 5 & $33333 \times 33333$ & $66666 \times 666666$ & $999999 \times 99999$ \\
DLA 5 Product 5th Generation & 1111088889 & 4444355556 & 9999800001 \\
ISM DLA 6 & $333333 \times 333333$ & $6666666 \times 66666666$ & $999999 \times 9999999$ \\
DLA 6 Product 6th Generation & 111110888889 & 444443555556 & 9999980000001 \\
\hline
\end{tabular}

Key: $L, L_{1} L_{2}:$ Kenizers in ISM 3,6,9; T, $T_{1}, T_{2}=$ Dekenizers in ISM 3,6,9

Figure 2: Isodigitation growths at two sites and growth facilitators of ISM 3,6,9.

Table 6: Plateaued Palindromic Isodigitals of Base 11 Potentiation Multiplication.

\begin{tabular}{|c|c|c|c|c|c|c|c|c|c|c|}
\hline & $\begin{array}{c}\text { Pow- } \\
\text { er } \\
\text { (n) }\end{array}$ & $11^{1}$ & $11^{2}$ & & $11^{3}$ & $11^{4}$ & & $11^{5}$ & $11^{6}$ & \\
\cline { 1 - 9 } \\
$\begin{array}{c}\text { Prod- } \\
\text { uct }\end{array}$ & 11 & 121 & 1331 & 14441 & 155551 & 1666661 & 1777771 \\
\hline
\end{tabular}




\section{Cancer Therapy \& Oncology International Journal}

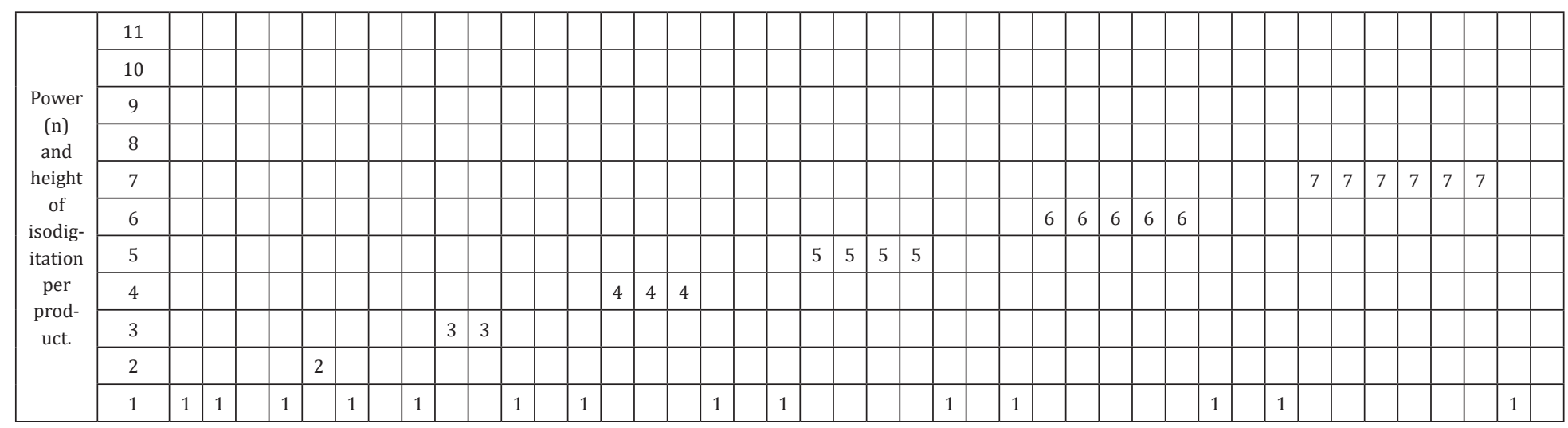

(a) (b)

(c)

(d)

(e)

(f) (g)
In Figure 2, Part A, at DLA 1 the Isodigital Square Multiplication (ISM) primary digit is 3 and the product 09 is called gamete, where the leading digit 0 is denoted $\mathrm{L}$ and the trailing digit 9, T. At DLA 2 the ISM $33 \times 33$ product 1089 is derived thus: the leading digit 0 of the gamete 09 becomes a kenizer and kenizes itself (adds 1 to itself) to form a kenizite, 1, as depicted in Table 5 and place it in its front, while the trailing digit 9 of the gamete also becomes a dekenizer and dekenizes itself (subtracts 1 from itself) as shown in Table 5 to form a dekenizite, 8 , and places it in its front to give altogether 1089 as shown in the ISM $33 \times 33$ DLA 2 product. At DLA 3, ISM 333x333 product grows to 110889 from 1089 due to insertion of one additional kenizite 1 in front of 0 and insertion of another additional dekenizite 8 in front of 9 to bring about the isodigitations evident at two sites for the first time. The digitations at the two sites continue to grow by one kenizite and one dekenizite with the progression of the DLA index of ISM as shown in the succeeding cases of Part A.

In Part B at DLA 1 the ISM 6x6 uses primary digit 6 to obtain the product 36 where 3 is the leading digit of the gamete 36 and 6 is the trailing digit. At DLA 2, the ISM 66 x 66 gives 4356. This is because 3 the leading digit of the gamete 36 at DLA 1 has become a kenizer in DLA 2 ISM and raised 4 as a kenizite for placement in its front, and 6 the trailing digit of the gamete 36 at DLA 1 has also become a dekenizer in DLA 2 ISM and raised 5 for placement in its front to give altogether 4356. At DLA3, The
ISM $666 \times 666$ yields 443556 as the product where isodigitation is evident at two sites for the first time because of the insertion of another kenizite 4 in from of 3 and another dekenizite 5 in front of 6 . The progression of the isodigitation at the two sites of ISM product with increasing DLA index is as explained before in Part A. Whence the isodigitation phenomenon in ISM 9x9 in Part $\mathrm{C}$ has the same explanation as those of 3 in Part A and 6 in Part B .

c. Plateaued palindromic pre-emptive Isodigitals

The growth pattern of the isodigitation in this case is based on potentiation index of base 11, whereby the incumbent potentiation power $(\mathrm{n})$ is replicated (n-1) times and sandwiched in 11 to make the product of potentiation multiplication of base 11 at various powers of potentiation. Hence given 14441, the digits I in front and I behind put together laterally give 11, which is known to be the potentiation base 11 , and the digit 4 indicates the potentiation power 4 while the isodigitation digitality of 3 for 444 is derived from the power 4 by dekenization ie. subtraction of 1 from 4 . In effect the population of the isodigitation consists of the power index (n) replicated (n-1) times and sandwiched in 11 to give the palindromic plateaued isodigital product always as depicted in Figure 2.

d. Non- Pre-emptive Isodigitals in three Subdivisions of Total, Partial and Twin

Table 4

Table 4: Types of Isodigitals, the Phenotypes of Tumours.

\begin{tabular}{|c|c|c|c|c|c|c|}
\hline \multicolumn{4}{|c|}{ Pre-emptive Isodigitals } & \multicolumn{3}{|c|}{ Non-pre-emptive Isodigitals } \\
\hline Types & \multicolumn{2}{|c|}{ Palindromic } & Non-palindromic & Total isodigitals & Partial isodigitals & Twin isodigitals \\
\hline & Peaked palindromic & Plateaued palindromic & Bifocal Isodigitality & & & 1122 \\
\hline Isodigitals & $\begin{array}{c}121 \\
12321 \\
1234321\end{array}$ & $\begin{array}{c}1331 \\
14441 \\
155551\end{array}$ & $\begin{array}{c}110889 \\
44435556 \\
9999800001\end{array}$ & $\begin{array}{c}111 \\
2222 \\
33333\end{array}$ & $\begin{array}{c}211 \\
2224 \\
53333\end{array}$ & $\begin{array}{c}1126 \\
33344 \\
556666\end{array}$ \\
\hline Source & Chart 1, SFN1, SFL 1 & Chart 2 & $\begin{array}{c}\text { Chart } 1 \text { SFN } 3 \\
\text { SFL } 3,6,9\end{array}$ & Base & gibreed to DLA $3 \mathrm{~s}$ & Chart 3 \\
\hline
\end{tabular}

\section{Keys:}

SFN 1: Sudit Family, No 1

SFL 1: Sudit Family Lineage 1

SFL 3, 6, 9: Sudit Family Lineages 3, 6, 9 


\section{Diagnosis}

They are commonplace in base 10 digibreed, the mega community of all integral numbers established by successive collateral posting as depicted in Chart 3. Each of them, no matter the type, has a unique and specific location in the base 10 mega community of numbers given by its own ROCI/RODI where RODI is the last digit of the number, and ROCI is the rest of the digits to the left of the RODI. The RODI, always single digit is domiciled in the base- strength of the digibreed displayed in the panel, while ROCI can be single or multidigital, depending on the DLA level of the number concerned and it is in a sequence domiciled in the corridor to the left of the digibreed field.

The two components come together during successive collateral posting in the serial formation of numbers: the ROD1 advancing geotropically (downward) in its column to the row of the ROCI, while the ROCI in the corridor advances amatropically (toward the right) in its row for konostatic placement (to the left) beside the RODI in its column, and form the number given ROCI/RODI in a unique and specific position in the mega number community. However, all integral numbers including the pre-emptive and non-per-emptive isodigitals share in the mode of formation and location in the base 10 digibreed, the mega community of numbers.

\section{Findings}

There are specific techniques for forming is digitations in numbers e.g. isodigital square multiplication (ISM) and Base 11 potentiation multiplication and Base 10 digibreed construction. There are digits favourable and digits unfavourable in ISM with respect of formation of isodigitations. For example, digits 3,6,9 of sudit family 3 and digit 1 of sudit family 1 alone are favourable for formation of isodigitation in numbers by ISM technique, while the rest of the five digits 2,5,8 in sudit family 2 , and 4 and 7 in sudit family 2 , are unfavourable. There are digits making up the DLA 1 product of ISM of digits 3, 6, 9 i.e. 09 for ISM 3;36 for ISM 6 and 81 for ISM 9 that initiate processes for creation of the isodigitation growth elements in the case of bifocal non- palindromic isodigitals. So, there are growth promoters in terms of digits and processes owed to agents of isodigitation in numbers. The foregoing aspects of isodigitals in numbers may well be found of tumours in humans.

\section{Conclusion and Significance}

Tumours as swellings of tissues in humans and isodigitals also of swellings in numbers are both manifestations of quantity. There is massive evidence of resemblance between tumours in humans and isodigitals in numbers in justification of tracking tumours into number community, initially attended by hesitancy. The issues of isodigitation growth pattern and growth promoters as well as selective engagement of four digits out of the nine counting digits revealed so far show the effort of probing the intricacies of isodigitation in number communities is worthwhile at least academically. The significance of tracking tumours into number community is that with the encouraging correspondence of the features of both tumours and isodigitals as manifestations of quantity, scientists can be challenged to take them as clues for further research on tumours, whether malignant or not in the interest of health care and well-being of humanity.

\section{Recommendations}

The striking resemblance between tumours in humans and isodigitals in numbers should be a food for thought amongst scientists in medicine and numeration science.

\section{References}

1. Arthur J Snider (1968) Numbers and Discoveries the Southwestern Company, Nashville, US.

2. Brown Watson (2003) The Amazing Universe English (Edn).

3. Sherman K. Stein (1976) Mathematics the Man-Made Universe an Introduction to the Spirit of Mathematics W.H. Freeman and Company, San Francisco, California, USA.

4. George K Stone (1964) Science in Action Prentice-Hall, Inc. Englewood Cliffs, New Jersey, USA.

5. Alma E. Guinness (Ed) (1987) ABC's of the Human Body. 
his work is licensed under Creative Commons Attribution 4.0 License DOI: 10.19080/CTOIJ.2019.14.555896

\section{Your next submission with Juniper Publishers} will reach you the below assets

- Quality Editorial service

- Swift Peer Review

- Reprints availability

- E-prints Service

- Manuscript Podcast for convenient understanding

- Global attainment for your research

- Manuscript accessibility in different formats

( Pdf, E-pub, Full Text, Audio)

- Unceasing customer service

Track the below URL for one-step submission https://juniperpublishers.com/online-submission.php 